\title{
Paradigm of Geological Mapping of the Adiyaman Fault Zone of Eastern Turkey Using Landsat 8 Remotely Sensed Data Coupled with PCA, ICA, and MNFA Techniques
}

\author{
Abdelrahman Khalifa ${ }^{1,2, *}$, Bashar Bashir ${ }^{3}{ }^{(0)}$, Ziyadin Çakir ${ }^{1}\left(\mathbb{D}\right.$, Şinasi Kaya ${ }^{4}$, Abdullah Alsalman ${ }^{3}$ and \\ Ahmed Henaish ${ }^{5}$ \\ 1 Department of Geological Engineering, Faculty of Mines, Istanbul Technical University, \\ Istanbul 34467, Turkey; ziyadin.cakir@itu.edu.tr \\ 2 Department of Geology, Faculty of Science, Al-Azhar University, Cairo 11651, Egypt \\ 3 Department of Civil Engineering, College of Engineering, King Saud University, Riyadh 11421, Saudi Arabia; \\ bbashir@ksu.edu.sa (B.B.); asalman@ksu.edu.sa (A.A.) \\ 4 Department of Geomatics, Faculty of Engineering, Istanbul Technical University, Istanbul 34467, Turkey; \\ kayasina@itu.edu.tr \\ 5 Department of Geology, Faculty of Science, Zagazig University, Cairo 44519, Egypt; \\ ahmed_henaish@zu.edu.eg \\ * Correspondence: akhalifa@azhar.edu.eg
}

Citation: Khalifa, A.; Bashir, B.; Çakir, Z.; Kaya, Ş.; Alsalman, A.; Henaish, A. Paradigm of Geological Mapping of the Adıyaman Fault Zone of Eastern Turkey Using Landsat 8 Remotely Sensed Data Coupled with PCA, ICA, and MNFA Techniques. ISPRS Int. J. Geo-Inf. 2021, 10, 368. https://doi.org/10.3390/ijgi10060368

Academic Editors:

Panagiotis Partsinevelos and Wolfgang Kainz

Received: 12 March 2021

Accepted: 25 May 2021

Published: 30 May 2021

Publisher's Note: MDPI stays neutral with regard to jurisdictional claims in published maps and institutional affiliations.

Copyright: (c) 2021 by the authors. Licensee MDPI, Basel, Switzerland. This article is an open access article distributed under the terms and conditions of the Creative Commons Attribution (CC BY) license (https:/ / creativecommons.org/licenses/by/ $4.0 /)$.

\begin{abstract}
A principal and independent component analysis (PCA and ICA) and a minimum noise fraction analysis (MNFA) were applied in this study to Landsat 8 Operational Land Imager (OLI) images along the Adiyaman fault zone in Eastern Turkey. These analyses indicated that the lithologic units, fault patterns, and the morphological and structural features can be mapped highly accurately by using spectral-matching techniques in regions where rocks are well exposed. An inspection of all possible band combinations indicated that the PCA 134 and 231 and the ICA 132 band combinations give the best false color composite images for identifying the lithological units and contacts. The findings of the MNFA band combinations show that the MNFA 521 band combination also is robust for discriminating the lithological units, particularly Quaternary clastic units (colluvium/alluvium). MNFA band 1 alone provides the best image for tracing the tectonic and structural elements in the study area. The new up-to-date lithologic map of the Adryaman fault zone we produced upon the interpretation of the processed OLI images reveals several river channels that are offset and beheaded by the Adiyaman fault, which verifies its Quaternary activity. This study demonstrated that, when used with the OLI data, the PCA, ICA, and MNFA are very powerful for lithological and structural mapping in actively deforming tectonic zones and hence can be applied to other regions elsewhere in the world where the climate is arid to semiarid, and the vegetation cover is scarce.
\end{abstract}

Keywords: principal and independent component analysis; minimum noise fraction analysis; lithologic and tectonic mapping; Adıyaman fault zone; Eastern Turkey

\section{Introduction}

The Adiyaman fault zone region in the southeast Anatolia still has no sufficient geological and tectonic studies, and thus further investigation and more discussion is required. In particular, the time, the seismic activities, updated geological mapping, and slip rate shearing are the most important areas to explore [1]. The study area is surrounded by the East Anatolian Fault (EAF), the Bitlis suture, and the Dead Sea Fault, where it covers $2611 \mathrm{~km}^{2}$ and is bounded between latitudes $37^{\circ} 35^{\prime} 20^{\prime \prime} \mathrm{N}$ and $37^{\circ} 56^{\prime} 38^{\prime \prime} \mathrm{N}$ and longitudes $37^{\circ} 58^{\prime} 16^{\prime \prime} \mathrm{E}$ and $38^{\circ} 44^{\prime} 54^{\prime \prime} \mathrm{E}$. (Figure 1). The recent seismic record associated with the Adiyaman fault is characterized by a low to moderate frequency of earthquakes. The Mw 5.5 Adiyaman Samsat earthquake was the greatest recorded along the fault, and it started at 14:07 (local time) on 2 March 2017 [1]. Processing of multispectral digital 
images using remote sensing technique has greatly advanced in the differentiation of lithological units and deposits, tectonic elements, and other geological and topographical features (e.g., [2-12]). Satellite data such as the Landsat Thematic Mapper (TM) and Enhanced Thematic Mapper (ETM+), ASTER, Landsat 8 (OLI), and Sentinel imagery provide information and clues that are very valuable in lithological and structural mapping. In the Eastern Desert of Egypt, lithological maps were initiated using Landsat Thematic Mapper (TM) data [13]. Landsat Enhanced Thematic Mapper (ETM+) data have been applied for the lithological and structural mapping of Central Côte d'Ivoire, Western Africa [14]. The authors in Ref. [15] performed remote sensing techniques to compare between Landsats ETM+ and OLI in mapping geological units and visualizing lineaments. ASTER data were analyzed by [15] to define the lithological units in the mountain pass region in California.

Based on the results obtained by satellite data processing, every multispectral band carries unique energy that extracts information from the Earth's surface, and thus image interpretations are based on textures, color, and spectral signatures to detect and trace the different elements and contacts that form deposits and rocks [5]. Satellite images processing and enhancement provide detailed clear images from the highly correlated bands that comprise most of the lithological information [16]. Mapping of tectonic structures and lineaments and their precise trends are very important tasks that allow us to visualize the architecture of the underlying rock basement [17]. The authors in Ref. [18] explained that tectonic lineaments extraction processing may be done by either automatic extraction or manual visualization using some open source and commercial software.

The present contribution is an integrated work that utilizes remote sensing and geographic information system techniques in order to investigate the Adiyaman fault zone region. In this work, we explore combinations of bands obtained through the principal and independent component analysis (PCA and ICA) and maximum noise fraction analysis (MNFA) of the OLI data for lithological and tectonic mapping. Based on the analysis of the results, we report optimal band combinations for this purpose and subsequently update the geological and tectonic map of the Adryaman fault zone, thereby providing a more detailed map of lithological units and tectonic features.

\section{Geologic Setting}

The Southeastern Anatolia area represents a forearc basin where the Neotethys lithosphere was consumed by subduction until the beginning of Late Cretaceous-Miocene [19]. It was affected by the primary deformation of the Arabia-Anatolia plates with the continentalcontinental collision zone [19]. The study area is located along with the left-lateral strikeslip Adiyaman fault that extends $\approx 75 \mathrm{~km}$, trending $65^{\circ} \mathrm{NE}$ south of the East Anatolian fault zone (EAFZ) in Eastern Turkey (Figure 1). The Adiyaman fault represents one of many faults that are mainly parallel to the main trend of the EAFZ [1]. The seismic activities that were recorded along the Adiyaman fault is characterized by moderate magnitude earthquakes [1]. The authors in Ref. [20] suggested that the Adryaman fault could have been formed at the same time as the East Anatolian Fault, which is in Late MioceneEarly Pliocene.

The study area mainly consists of autochthonous sedimentary rocks. Generally, major type rocks are represented by Plio-Quaternary undifferentiated clastic and carbonate rocks, Middle-Upper Miocene clastic rocks, and Upper Cretaceous ophiolitic mélange rocks [1]. In the southern part of the Adiyaman fault, two-thirds of the area are represented by Middle-Upper Miocene continental clastic rocks, and Plio-Quaternary undifferentiated materials. They cover around one-third of the area of the northern part of the Adryaman fault (Figure 2). The Middle Triassic-Cretaceous volcanic and sedimentary rocks are dominant in the northern part of the Adiyaman fault, which cover at least one-third of that part. The only allochthon unit in the study area is represented by an elongated body of Upper Cretaceous ophiolitic mélange (Figure 2). The Eocene neritic limestone is located in the northern part of the study area, shaped with an elongated body that is parallel to 
the fault trace. Eocene neritic limestone is located also in the northeastern, northwestern, southeastern, southwestern, and central parts of the study area (Figure 2). In the middle of the study area, the Eocene limestone shows tectonic contact; it is surrounded by tectonic structures, which seem to suggest transtensional activity of the Adiyaman fault in that zone. The lower Eocene continental clastic rocks in association with clastic and carbonate rocks of Upper Cretaceous-Paleocene and Upper Cretaceous, respectively, are represented by elongated thin bodies in the northern part of the fault, whereas the clastic and carbonate rocks are located in other parts of the study area (Figure 2). Cretaceous pelagic limestone is recorded on the western side of the fault zone (Figure 2). The rest of the lithologic units are distributed in small parts all over the study area (Figure 2). Most of these lithologic units can be detected in standard color infrared images (Figure 2) and in decorrelation stretch image products because of their color and textural characteristics. Maximum lithological information is extracted from OLI data when spectral analysis and image interpretative analysis are used together.

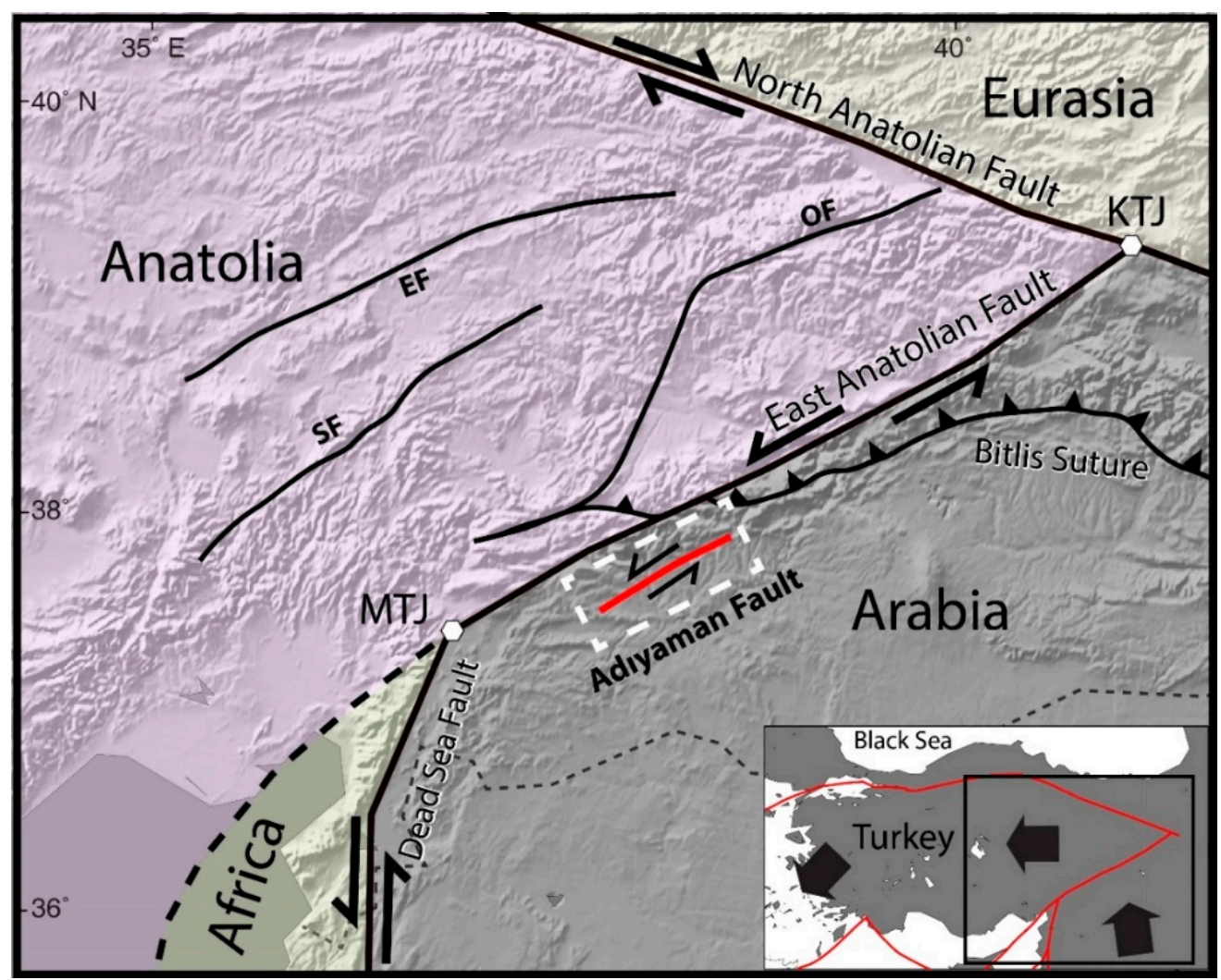

Figure 1. Shaded relief image (data from SRTM-30 [21]) of Eastern Turkey, showing the African, Arabian, Anatolian, and Eurasian lithospheric plates and major active faults (in thick black lines). The Adiyaman fault is shown by a thick red line. Abbreviations: MTJ, Maraş triple junction; KTJ, Karlıova triple junction; EF, Ecemiş fault; SF, Savrun fault; OF, Ovacık fault. Thick black arrows indicate the plates' movement. The box with white dashed lines shows the location of the study area and Figure 2, respectively. 


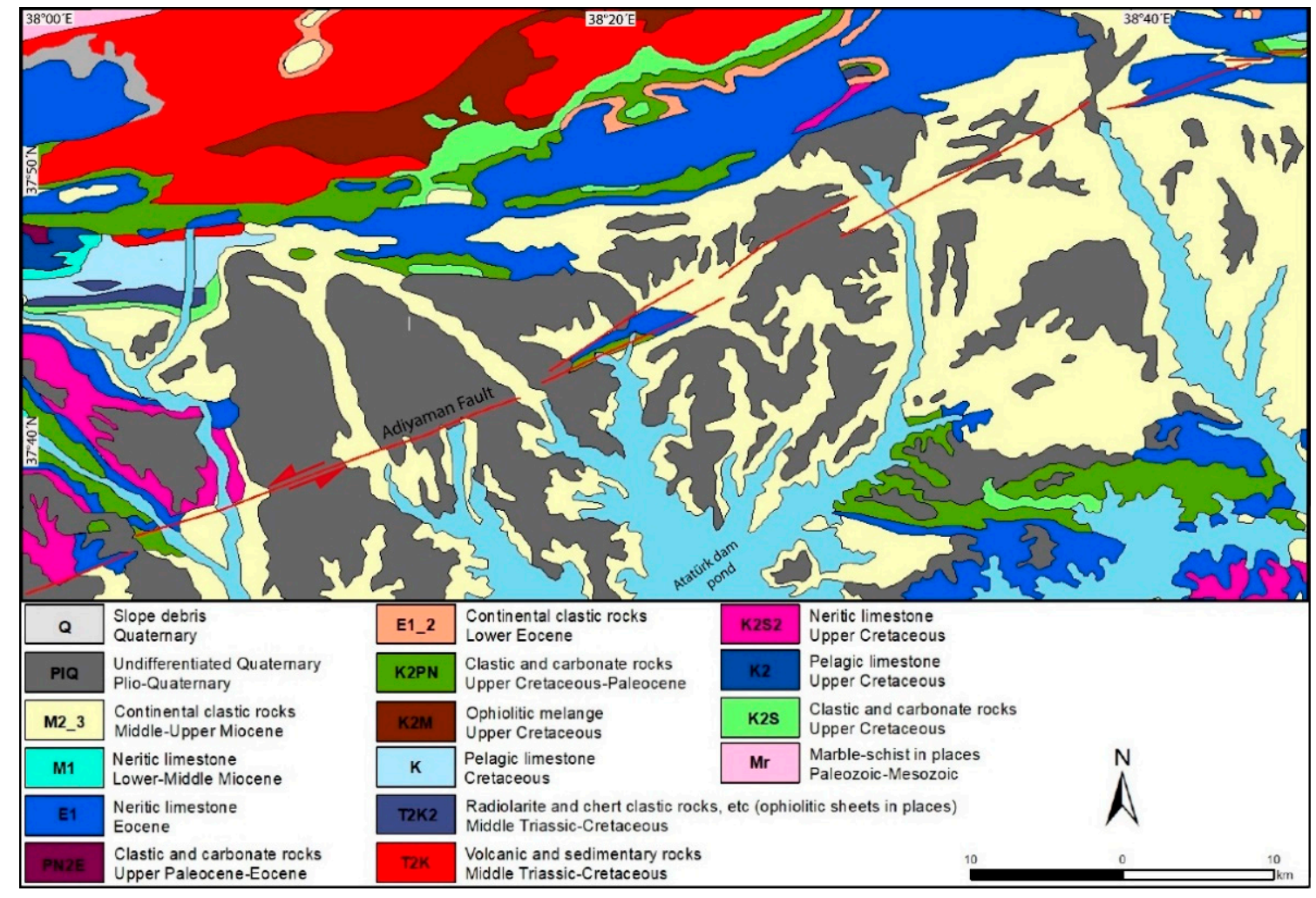

Figure 2. Lithologic map of the Adıyaman fault zone (from [22]).

\section{Data}

In this study, remote sensing data were acquired by the Landsat 8 (OLI) satellite, which detects and records the reflected and emitted electromagnetic radiation (EMR) images of the Earth during a 16-day repeat round on the Worldwide Reference System-2 system. Landsat 8 (OLI) has two sensors on board: the Operational Land Imager (OLI) and thermal infrared sensors (TIRS). These two sensors provide seasonal coverage of the global landmass of visible, NIR, SWIR, thermal, and panchromatic at a spatial resolution of $30 \mathrm{~m}$ (visible, NIR, SWIR), $15 \mathrm{~m}$ (panchromatic), and $100 \mathrm{~m}$ (thermal). The multispectral and panchromatic wavelength regions offer complementary data for lithological mapping.

In this work, the cloud-free Landsat 8 scene (path 173/row 34) recorded on 10 September 2016 was processed. A metadata file is required for the preprocessing operation, which was applied in order to obtain spatially and radiometrically corrected images to be well prepared for analyzing spectral data. It is significant to note that the raw data have some residual errors that affect the accuracy of the resulted geological information $[23,24]$.

\section{Methodology}

The present work relies on applying remote sensing techniques in updating lithological and tectonic mapping. Preprocessed and processed operations were applied to the selected used remote sensing data (Landsat 8, OLI) such as pre-georeferenced, atmospheric correction, principal component analysis (PCA), and independent component analysis (ICA). The data were processed and analyzed in addition to creating different maps depending on different software packages, including ERDAS Imagine 9.2, ENVI 5, ArcGIS (10.4), and Adobe illustrator (CC 2017).

\subsection{Image Preprocessing}

Crosstalk and atmospheric effects are high in radiance with bands 5 and 9 because of the energy transmission from the optical band 4 to the bands 5 and 9 detectors. The Fast Line-of-sight Atmospheric Analysis of Spectral Hypercubes (FLAASH) atmospheric 
correction model was used to examine the surface reflectance in order to minimize the atmospheric attenuations and to obtain reflectance imagery [23,24]. Although the FLAASH processing step is a standard technique for compensating error, the raw data have some residual errors that affect the accuracy of the resulted geological information [24]. The atmospheric correction was operated by ENVI 5 through the following algorithms:

$$
\begin{gathered}
(\text { B1 le } 0) \times 0+(\text { B1 ge } 10000) \times 1+(B 1 \text { gt } 0 \text { and } B 1 \text { lt } 10000) \times \text { float }(B 1) / 10000 \\
(\text { B1 le } 0) \times 0+(B 1 \text { ge } 1) \times 1+(B 1 \text { gt } 0 \text { and } B 1 \text { lt } 1) \times \text { float }(B 1) / 1
\end{gathered}
$$

The raw Landsat 8 scene is followed by a subsetting operation in order to focus on the concerned area.

\subsection{Image Processing and Enhancement}

Satellite image processing and enhancement steps were performed by running different algorithms and techniques, such as a principal component analysis, independent component analysis (ICA), and minimum noise fraction analysis (MNFA).

\subsubsection{Principal and Independent Component Analysis}

PCA and ICA are techniques that are applied to multispectral and hyperspectral remotely sensed datasets. These two are statistical transformations that extract information from second-order statistics and to high-order statistics, respectively. PCA and ICA methods are very helpful for detecting and defining a smaller number of uncorrelated variables from a large set of data [25]. These are applied to give uncorrelated output different bands and to detect noise components, and this is performed by defining new dataset orthogonal axes.

We used the principal and independent component analysis (PCA and ICA) techniques to produce enhanced contrast images in a false color composite (FCC). These data have their origin at the data mean and are rotated; thus, data distinction can be maximized [26]. The result images of the principal component analysis (PCA) bands of the same number could be applied as the input spectral numbers [26].

As expected, according to the PCA bands' data variance that we obtained, PCA band 1 has the largest data variance, and the amount of data variance decreases gradually with the PCA bands until the last PCA bands (PCA bands 6 and 7), which appear noisy because they cover very little data variance, much of which is due to the noise in the original data. Depending on the ICA band data, the first ICA band covers the largest amount of geological information, while the last ICA bands show noisy images because they carry very small data variance.

\subsubsection{Minimum Noise Fraction Analysis (MNFA)}

The second effective method that we applied along the study fault zone is the minimum noise fraction analysis (MNFA), which is a method for hyperspectral imagery denoising through a linear transformation action with two different steps. First, we applied a noise covariance matrix to decorrelate and rescale the noise in the processing data [27-32]. In this method, the noise has unit variance and no band-to-band correlations; In the second step, we applied a standard PCA transform to the raw data noise [33]. The MNFA method is a variation of the principal component analysis (PCA) steps, formed with minimum spatially incoherent noise to higher bands that could be excluded from the next step of the processing analysis $[28,33]$. In addition to applying the MNFA processing method, the information that is characterized by the dimensionality of remote sensing data could be analyzed by MNFA processing as well [34]. The largest data variance percentage exists in the first MNFA band, and the second MNFA band has the next largest data variance, and so on. 


\section{Results and Discussion}

\subsection{Landsat 8 Principal and Independent Component Analysis}

Interpretation of the transformed data through techniques such as PCA and ICA provides detailed band information, while separating the data along a new component can be analyzed by visualizing the new FCC components [35]. From the result of the PCA 7-band analysis, we detected two sets of PCA band combinations, i.e., bands 134 and 231, for the best discrimination between pre-Miocene and post-Miocene rocks. The geologic interpretation of OLI PCA bands indicates that the different lithologic units and the boundaries between them can be better separated and defined. PCA band combinations show obvious contacts between the different lithologic units.

In the PCA RGB-134 image (Figure 3a,b), the Eocene neritic limestone is well detected from the adjacent rocks in light green, while undifferentiated Quaternary units are in yellowish-green, volcanic and sedimentary rocks are in pale violet, and ophiolitic mélange is in violet. In the PCA RGB-231 image (Figure 4a,b), the Eocene neritic limestone is in blue, while undifferentiated Quaternary units are clearly in light green, volcanic and sedimentary rocks are in greenish-blue, and ophiolitic mélange is in dark pink. From the processing ICA 7-bands, we conclude that the RGB-231 band combination provides the best image for differentiating the Miocene lithological units.

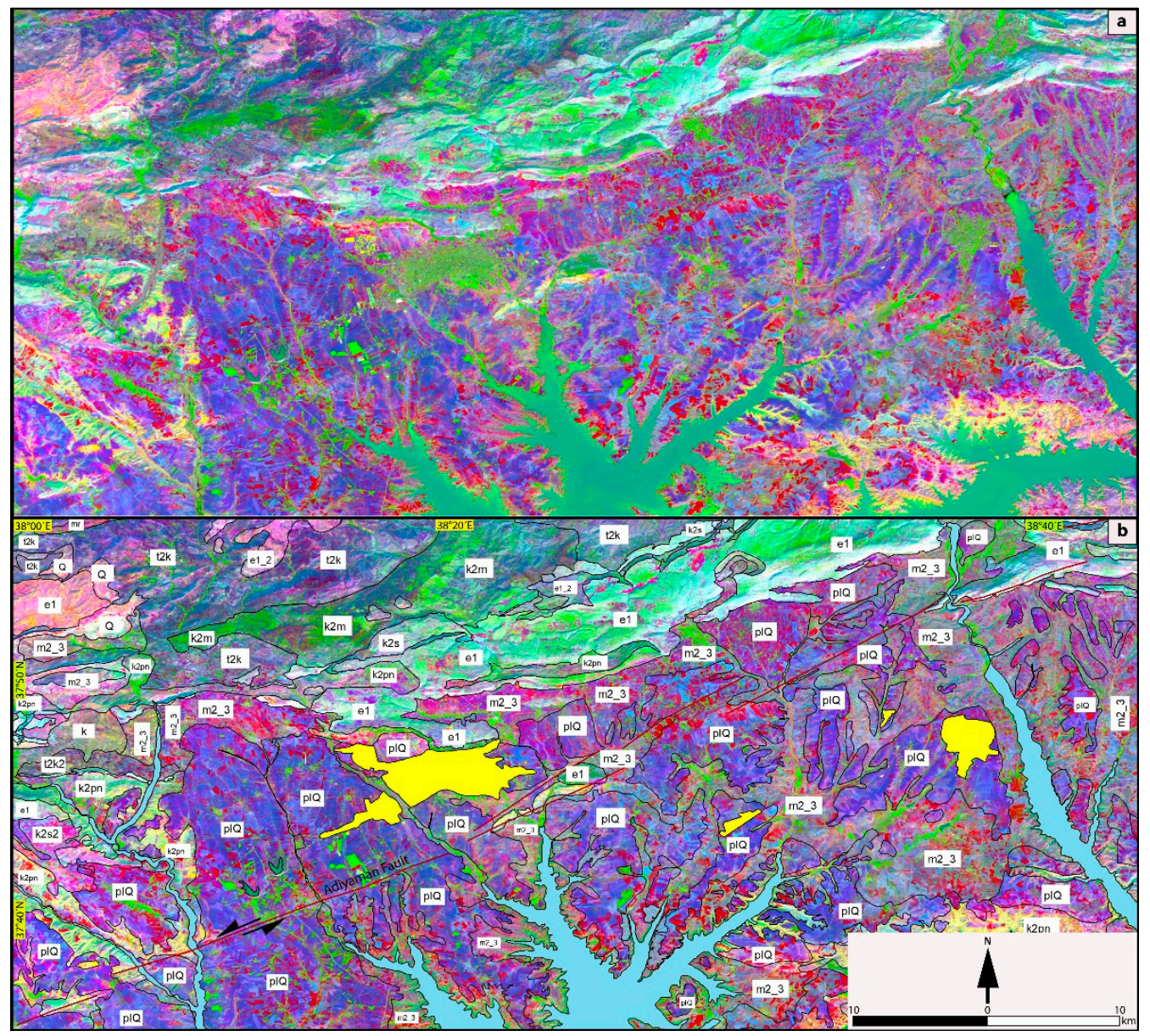

Figure 3. (a) Landsat 8 principal component analysis RGB-134 image. (b) PCA image with lithological polygons. Areas of settlements are defined by yellow polygons. 


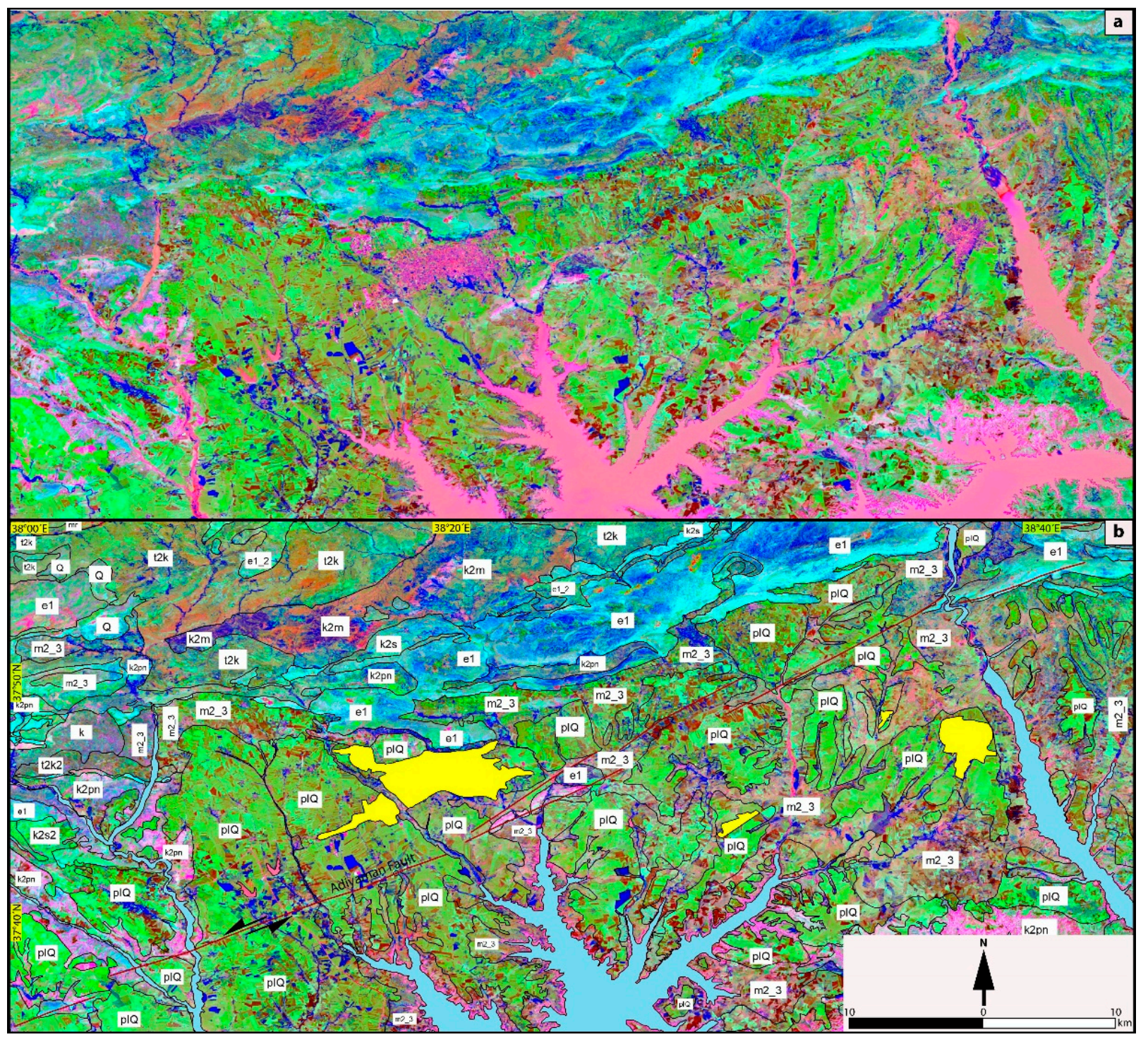

Figure 4. (a) Landsat 8 principal component analysis RGB-231 image. (b) PCA image with lithological polygons. Areas of settlements are defined by yellow polygons.

In the ICA RGB-132 image (Figure 5a,b), the neritic limestone of Eocene age is shown in greenish-red, while undifferentiated Quaternary units are well outlined in yellow, volcanic and sedimentary rocks are in light green, and ophiolitic mélange is in dark green.

\subsection{Landsat 8 Minimum Noise Fraction Analysis}

Our analysis of the MNFA bands shows that the RGB- 521 band combination is the best one for discriminating the different lithologic units of the study area. MNFA band 1 alone provides the best image for tracing the tectonic and structural elements in the study region.

The geologic interpretation of the MNFA RGB-521 image (Figure 6a,b) suggests that undifferentiated Quaternary units are shown in sharp pink with a coarse crystalline texture, while Middle-Upper Miocene continental clastic rocks are in light yellowish-pink, the volcanic and sedimentary units are in greenish-pink, and ophiolitic mélange is in light violet. 


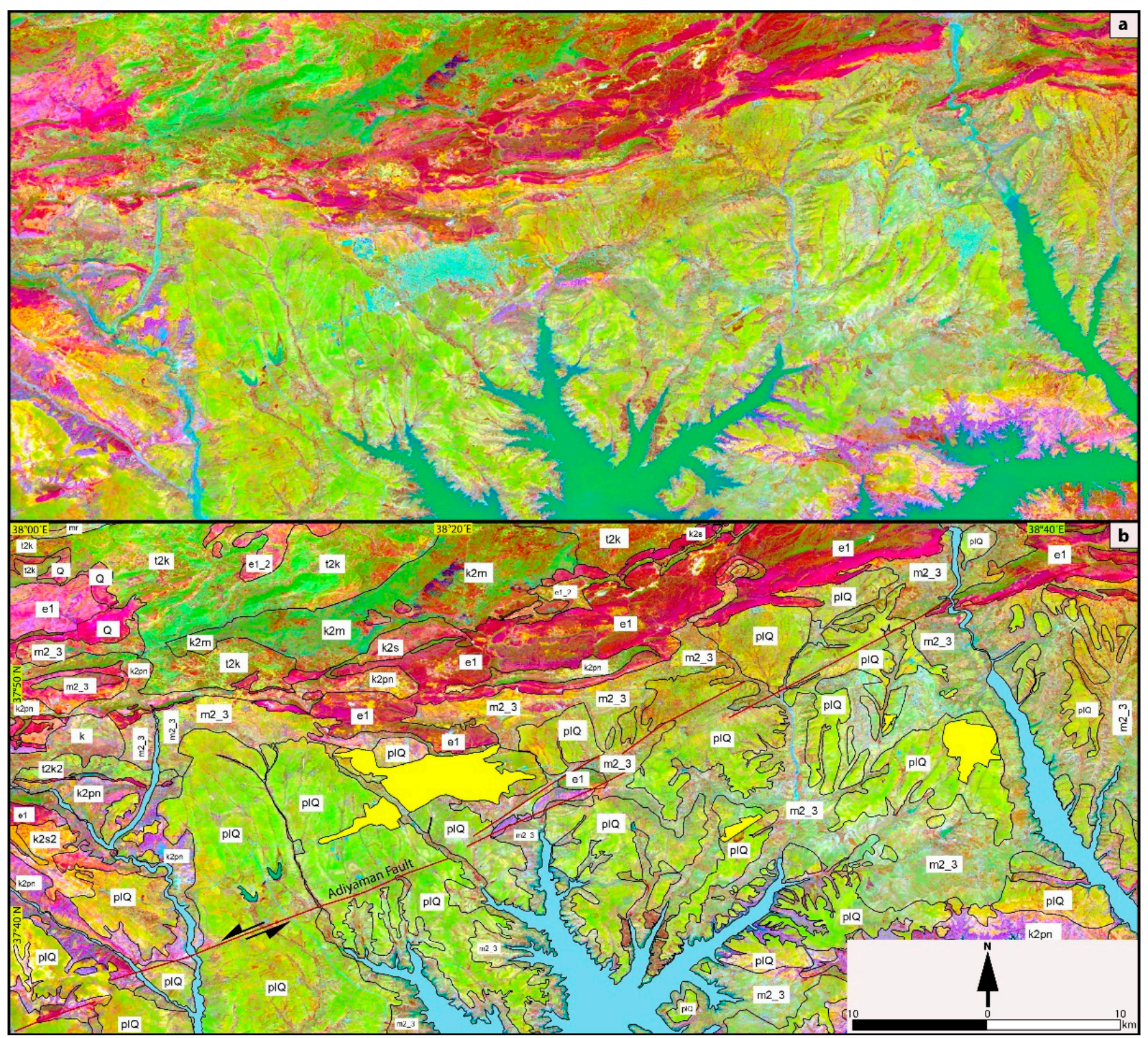

Figure 5. (a) Landsat 8 independent component analysis RGB-132 image. (b) ICA image with lithological polygons. Areas of settlements are defined by yellow polygons.

The results show that the first four high-order bands principal components and minimum noise fraction analyses $(1,2,3$, and 4 ) have over $99 \%$ of spectral information, and so it is generally accepted that these are widely used for lithological mapping rather than the low-order principal components and minimum noise fraction analysis $(5,6,7$, etc.) that usually contain low signal-to-noise ratios. The principal component and minimum noise higher order give good information about the occurrence of rock types that are dominant in the map image. Therefore, it is sometimes worthwhile to apply a combination of certain lower order analyses that cover some of the information with higher order to detect and highlight some target spectral signatures. In this article, the lowest order MNFA 5 minimum noise in addition to the higher-order MNFA 1st and 2nd minimum fraction noise give a signal to discriminate the dominant rock types in the study area (Figure 6). PCA, ICA, and MNFA are statistics-based, and the results may vary in the same area with different geographic sizes. 


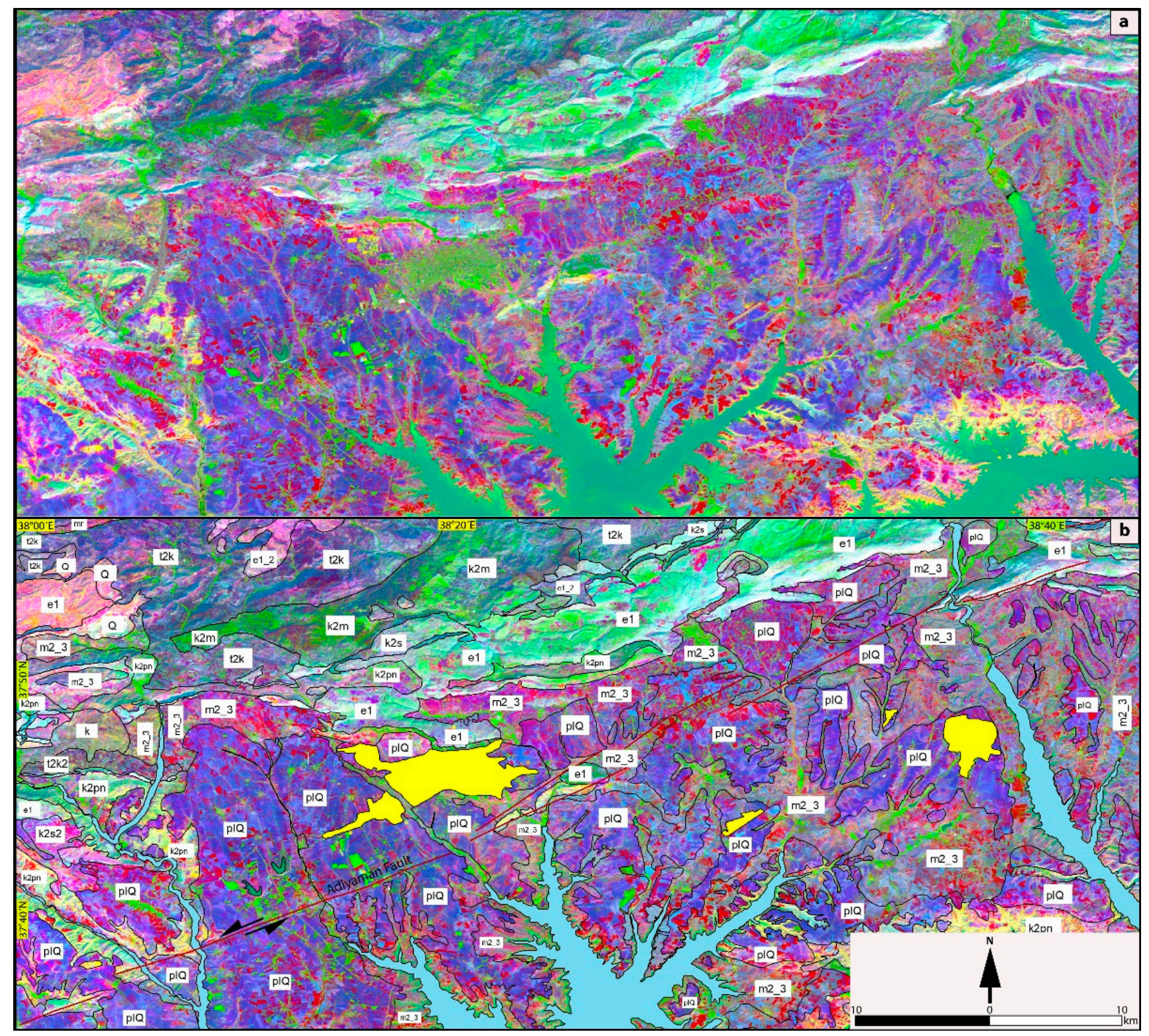

Figure 6. (a) Landsat 8 minimum noise fraction RGB-521 image. (b) MNFA image with lithological polygons. Areas of settlements are defined by yellow polygons.

\subsection{Extracted Structural Map}

The tectonic elements were extracted manually from the first MNF band as it reveals the geological structures the best. The Adryaman fault is the main tectonic element along the study region, which can be precisely traced [1]. Most of the structural lineaments and roads over the Adiyaman fault region were mapped according to the authors in [1,22]. The structures that are mapped in this work are in agreement with the work in [1,22]. Referring to the geological map in [22], the traces of reverse and thrust faults located along the northeastern, northern, and northwestern parts of the region were refined (Figure 7). From the MNFA band 1, it is easy to notice and detect some settlements areas along the fault trace. 


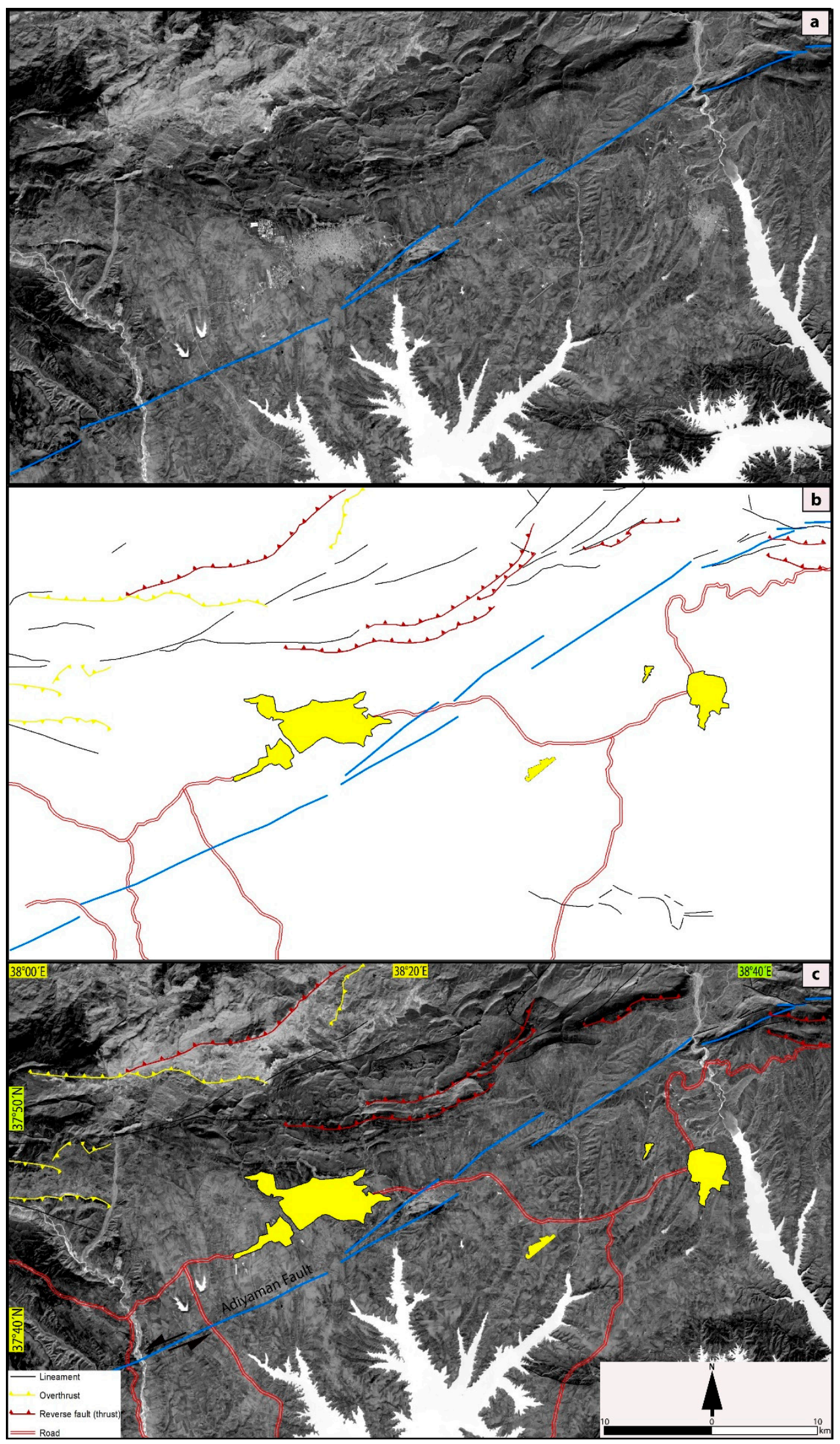

Figure 7. (a) Landsat 8 MNFA band 1; (b) structural map of the study region; (c) structural map layer over MNF band 1. Areas of settlements are defined by yellow polygons. 


\subsection{Improvements of the Available Lithological Map}

Our new map shows differences in the distribution of some lithological units and boundaries between them compared to the published geological map [35] (Figure 2). The most obvious differences are the discrimination between the Eocene, neritic limestone, Middle-Upper Miocene, continental clastic rocks, and undifferentiated Quaternary units. In the southeastern part, the new map defined the Plio-Quaternary units instead of Eocene neritic limestone (Figures 2 and 8). In the west, the results replaced the Middle-Upper Miocene continental clastic rocks with Upper Cretaceous-Paleocene clastic carbonate rocks (Figures 2 and 8 ). The resulted images could not detect the contact between the radiolarite with chert clastic rocks units. The appearance of the pelagic limestone is similar to the Middle-Upper Miocene rocks, and thus the paper mapped them as the same continental clastic unit (Figures 2 and 8 ).

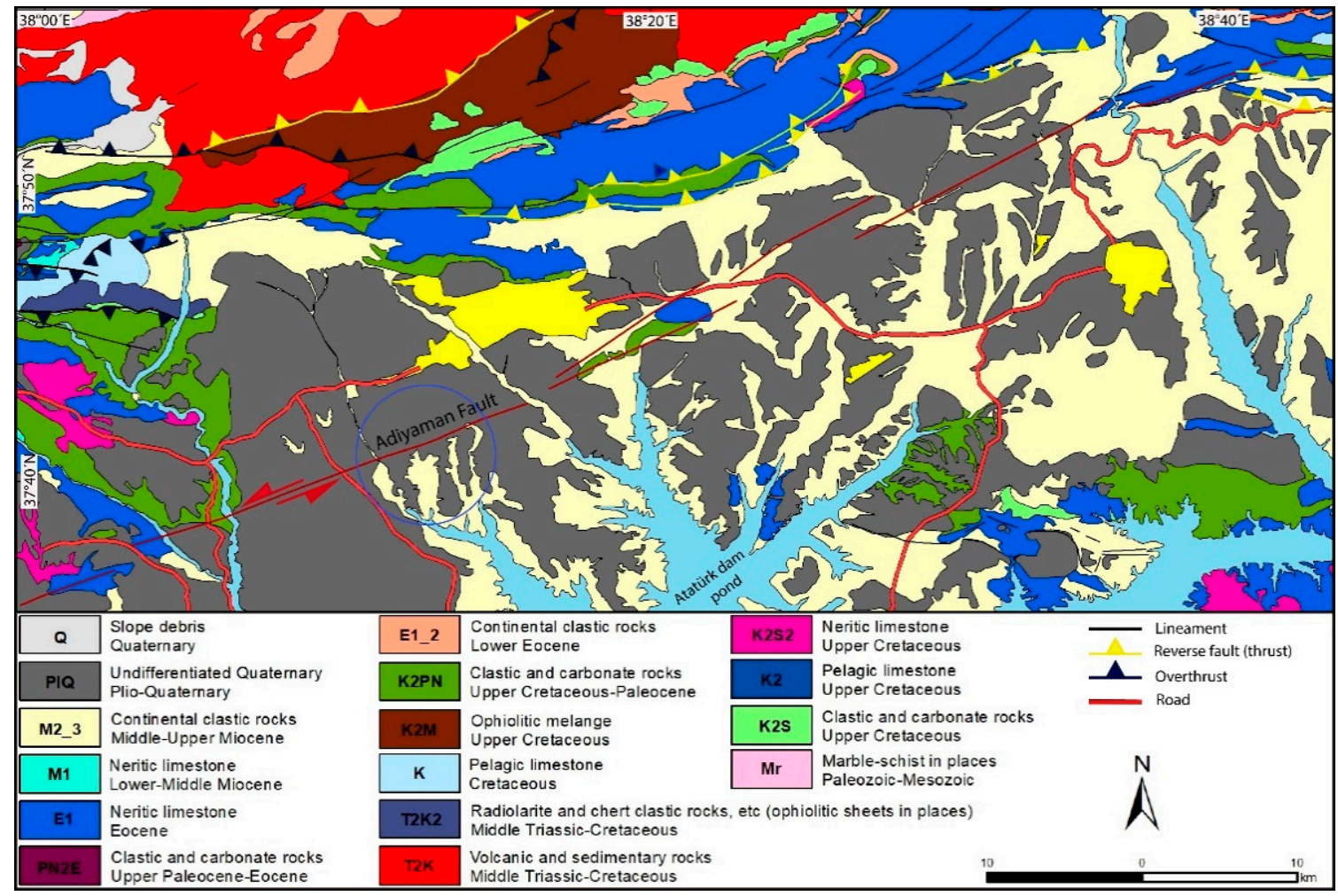

Figure 8. Refined lithological and structural map obtained in this study. Blue circle indicates the region where offset river channels are revealed by the new map. Note the difference between the two maps; in the new map, formation contacts are refined, and some outcrops are found to be missing in the published geology map. Areas of settlements are defined by yellow polygons.

\section{Conclusions}

In this work, the Landsat OLI data were processed using the principal and independent component analysis and the minimum noise fraction analysis to map the pre- and post-Miocene rocks along the Adiyaman fault zone. The results demonstrate that PCA 134 and 231, ICA 132, and MNFA 521 are the band combinations of the Landsat OLI data that provide the best images for mapping lithologic units and can therefore be used as a timeand cost-effective approach for mapping in tectonically active regions elsewhere in the world. In our study, the morphology of the Adiyaman fault was better revealed by the MNFA band 1. The MNFA 521 band combination appears to be the best combination to map Quaternary alluvial deposits with high accuracy. As can be seen in Figure 2, the new map shows in details the contacts and distribution of undifferentiated Quaternary clastic rocks along the Adiyaman fault compared to the available geological map [22]. The map 
reveals the presence of offset river channels along the Adiyaman fault at around $38.15^{\circ} \mathrm{E}$ longitude, where there the river channels do not cross the fault to the north but stop right at the fault line, implying that these channels were recursively offset by the fault, and thus the Adiyaman fault is a Quaternary active fault.

In addition to the refinement of all the boundaries of rock formations, our study revealed various outcrops that are missing in the geological map by Herece [22], particularly in the southern and western parts of the Adiyaman fault zone. Some structures were traced and extrapolated according to regional geology [22] and previous work [1], while some were traced or refined for the first time, such as reverse and overthrust faults. The study confirms that geological surveys in the new outcrops are necessary for verifying what has been observed from satellite images.

Author Contributions: Data acquisition, Abdelrahman Khalifa, Bashar Bashir., and Ziyadin Çakir; data correction and manipulation, Abdelrahman Khalifa, Bashar Bashir, and Abdullah Alsalman; funding acquisition, Bashar Bashir and Abdullah Alsalman; data processing, Abdelrahman Khalifa, Bashar Bashir, Abdullah Alsalman, and Ahmed Henaish; geological interpretation, Abdelrahman Khalifa and Ahmed Henaish; software, Abdelrahman Khalifa, Ziyadin Çakir, Şinasi Kaya, and Bashar Bashir; project administration, Bashar Bashirand Abdullah Alsalman; results and discussion, Abdelrahman Khalifa, Ziyadin Çakir, Şinasi Kaya, and Bashar Bashir; writing-original draft, Abdelrahman Khalifa; review and editing, Ziyadin Çakir. and Abdullah Alsalman. All authors have read and agreed to the published version of the manuscript.

Funding: This work is supported by the Researchers Supporting Project, grant number RSP-2020/296, King Saud University, Riyadh, Saudi Arabia.

Institutional Review Board Statement: Not applicable.

Informed Consent Statement: Not applicable.

Data Availability Statement: Not applicable.

Acknowledgments: Cengiz Zabc1 and Adel Seliem are greatly acknowledged for their valuable comments. The authors would also like to acknowledge the structure and tectonic lab team, the geology department in the Faculty of Science at Al-Azhar University for their assistance in data processing and methodologies.

Conflicts of Interest: The authors declare no conflict of interest.

\section{References}

1. Khalifa, A.; Çakir., Z.; Owen, A.; Kaya, Ş. Evaluation of the Relative Tectonic Activity of the Adıyaman fault within the Arabian-Anatolian plate boundary (eastern Turkey). Geologicaacta 2019, 17. [CrossRef]

2. Sabins, F. Remote Sensing Principles and Interpretation, 3rd ed.; Freeman: New York, NY, USA, 1997; 494p.

3. Hamimi, Z.; Hagag, W.; Kamh, S.; El-Araby, A. Application of remote-sensing techniques in geological and structural mapping of Atalla Shear Zone and Environs, Central Eastern Desert, Egypt. Arab. J. Geosci. 2020, 13, 414. [CrossRef]

4. Gad, S.; Kusky, T.M. ASTER spectral ratioing for lithological mapping in the Arabian-Nubian shield, the Neoproterozoic Wadi Kid area, Sinai, Egypt. Gondwana Res. 2007, 11, 326-335. [CrossRef]

5. Mwaniki, M.W.; Moeller, M.S.; Schellmann, G. A comparison of Landsat 8 (OLI) and Landsat 7 (ETM+) in mapping geology and visualizing lineaments: A case study of central region Kenya. In Proceedings of the 36th International Symposium on Remote Sensing of Environment, Berlin, Germany, 11-15 May 2015; Volume 11, pp. 897-903.

6. Abdel Gawad, A.E.; Abu Donia, A.M.; Elsaid, M. Processing of landsat 8 imagery and ground gamma-ray spectrometery for geologic mappin and dose-rate assessment, Wadi Diit along the Red Sea Coast, Egypt. Open J. Geol. 2016, 6, 911-930. [CrossRef]

7. Ahmadirouhani, R.; Rahimi, B.; Karimpour, M.H.; Shafaroudi, A.M.; Najafi, S.A.; Pour, A.B. Fracture mapping of lineaments andrecognizing their tectonic significant using Spot-5 satellite data: A case study from the Bajestand area, Lut block, east of Iran. J. Afr. Earth Sci. 2017, 134, 600-612. [CrossRef]

8. Das, S.; Pardeshi, S.D.; Kulkarni, P.P.; Doke, A. Extraction of lineaments from different azimuth angles using geospatial techniques: A case study of Pravara basin, maharashtra, India. Arab. J. Geosci. 2018, 11, 160. [CrossRef]

9. Al-Djazouli, M.O.; Elmorabiti, K.; Zoheir, B.; Rahimi, A.; Amellah, O. Use of Landsat-8 data for delineating fracture systems in subsoil regions: Implications for groundwater prospection in the Waddai area, eastern Chad. Arab. J. Geosci. 2019, $12,241$. [CrossRef] 
10. Ourhzif, Z.; Algouti, A.; Algouti, A.; Hadach, F. Lithological mapping using Landsat 8 OLI and Aster multispectral data in IminiOunilla District south high Atlas of Marrakech. In Proceedings of the ISPRS Geospatial Week 2019, Enschede, The Netherlands, 10-14 June 2019.

11. Khalifa, A.; Çakır, Z.; Kaya, S..; Gabr, S. ASTER spectral band ratios for lithological mapping: A case study for measuring geological offset along the Erkenek Segment of the East Anatolian Fault Zone, Turkey. Arab. J. Geosci. 2020, 13, 832. [CrossRef]

12. Sadek, M.; El-Kalioubi, B.A.; Ali-Bik, M.W.; El Hefnawi, M.A.; Elnazer, A.A. Utilizing Landsat-8 and ASTER data in geologic mapping of hyper-arid mountainous region: Case of Gabal Batoga area, South Eastern Desert of Egypt. Environ. Earth Sci. 2020, 79, 101. [CrossRef]

13. Gad, S.; Kusky, T.M. Lithological mapping in the Eastern Desert of Egypt, the Barramiya area, using Landsat thematic mapper (TM). J. Afr. Earth Sci. 2006, 44, 196-202. [CrossRef]

14. Allou, G.; Ouattara, G.; Coulibaly, Y.; Bonin, B. The Landsat 7 ETM+ remote sensing imagery for lithological and structural mapping in the central Côte D'ivoire (western Africa): Case of Dabakala area. Eur. Sci. J. 2015, 11, 141-163.

15. Rowan, C.; John, C. Lithologic mapping in the mountain pass, California area using advanced spaceborne thermal emission and reflection radiometer (ASTER) data. Remote Sens. Environ. 2003, 84, 350-366. [CrossRef]

16. Abdeen, M.M.; Abdelghaffar, A.A. Mapping Neoproterozoic structures along the central Allaqiheiani suture, Southeastern Egypt, using remote sensing and field data. In Proceedings of the 29th Asian Conference of Remote Sensing (Abstract), Colombo, Sri Lanka, 10-14 November 2008; p. 789.

17. Ramli, M.F.; Yusof, N.; Yusoff, M.K.; Juahir, H.; Shafri, H. Lineament mapping and its application in landslide hazard assessment: A review. Bull. Eng. Geol. Environ. 2010, 69, 215-233. [CrossRef]

18. Marghany, M.; Hashim, M. Lineament mapping using multispectral remote sensing satellite data. Int. J. Phys. Sci. 2010, 5, 1501-1507. [CrossRef]

19. Irmak, T.S.; Bulut, İ.; Doğan, B. Regional seismicity in Adiyaman-Samsat (SE Turkey). Boll. Geofis. Teor. Appl. 2020, $451,468$.

20. Şengör, C.; Görür, N.; Şaroglu, F. Strike-slip faulting and related basin formation in zones of tectonic escape: Turkey as a case study. In Strike-Slip Faulting and Basin Formation; Biddle, K.T., Christie-Slick, N., Eds.; SEPM Society for Sedimentary Geology, Oklahoma, Special Publications: Broken Arrow, OK, USA, 1985; Volume 37, pp. 227-264.

21. Farr, T.G.; Rosen, P.A.; Caro, E.; Crippen, R.; Duren, R.; Hensley, S.; Kobrick, M.; Paller, M.; Rodriguez, E.; Roth, L.; et al. The shuttle radar topography mission. Rev. Geophys. 2007, 45. [CrossRef]

22. Herece, E. Atlas of the East Anatolian Fault; Special Publication Series; General Directorate of Mineral Research and Exploration (MTA): Ankara, Turkey, 2008; 359p.

23. Zhang, T.; Yi, G.; Li, H.; Wang, Z.; Tang, J.; Zhong, K.; Li, Y.; Wang, Q.; Bie, X. Integrating Data of ASTER and Landsat-8 OLI (AO) for Hydrothermal Alteration Mineral Mapping in Duolong Porphyry Cu-Au Deposit, Tibetan Plateau, China. Remote Sens. 2016, 8, 890. [CrossRef]

24. Mars, J.C.; Rowan, L.C. Spectral assessment of new ASTER SWIR surface reflectance data products for spectroscopic mapping of rocks and minerals. Remote Sens. Environ. 2010, 114, 2011-2025. [CrossRef]

25. Hewson, R.; Cudahy, T. Issues Affecting Geological Mapping with ASTER Data: A Case Study of the Mt Fitton Area, South Australia. In Land Remote Sensing and Global Environmental Change; Ramachandran, B., Justice, C.O., Eds.; Series Remote Sensing and Digital Image Processing 13; Springer: New York, NY, USA, 2010; Volume 11, pp. 273-300.

26. Amer, R.; Kusky, T.; Gullam, A. Lithological mapping in the Central Eastern Desert of Egypt using ASTER data. J. Afr. Earth Sci. 2010, 56, 75-82. [CrossRef]

27. Kumar, C.; Shetty, A.; Raval, S.; Sharma, R.; Champati, R. Lithological discrimination and mapping using ASTER SWIR data in the Udaipur area of Rajasthan, India. Procedia Earth Planet. Sci. 2015, 11, 180-188. [CrossRef]

28. Gurugnanam, B.; Arulbalaji, P.; Midhuna, V.; Kumaravel, S. Lithological discrimination of Anorthosite using ASTER data in Oddancehatram area, Dindigul district, tamil Nadu, India. Int. J. Adv. Eng. Manag. Sci. 2017, 3, 316-324.

29. Green, A.A.; Berman, M.; Switzer, P.; Craig, M.D. A trans-formation for ordering multispectral data in terms of image quality with implications for noise removal. IEEE Trans. Geo-Sci. Remote Sens. 1988, 26, 65-74. [CrossRef]

30. Lee, J.B.; Woodyatt, A.S.; Berman, M. Enhancement of high spectral resolution remote sensing data by a noise-adjusted principal components transform. IEEE Trans. Geosci. Remote Sens. 1990, 28, 295-304. [CrossRef]

31. Bjorgan, A.; Randeberg, L.L. Real-time noise removal for line-scanning hyperspectral devices using a minimum noise fractionbased approach. Sensors 2015, 15, 3362-3378. [CrossRef] [PubMed]

32. Nielsen, A.A. Kernel maximum autocorrelation factor and minimum noise fraction transformations. IEEE Trans. Image Process. 2011, 20, 612-624. [CrossRef]

33. Luo, G.; Chen, G.; Tian, L.; Qin, K.; Qian, E. Minimum noise fraction versus principle component analysis as a preprocessing step for hyperspectral imagery denoising. Can. J. Remote Sens. 2016, 42, 106-116. [CrossRef]

34. Hubbard, B.E.; Crowley, J.K. Mineral mapping on the Chilean-Bolivian Altiplano using co-orbital ALI, ASTER and Hyperion imagery: Data dimensionality issues and solutions. Remote Sens. Environ. 2005, 99, 173-186. [CrossRef]

35. Mwaniki, M.W.; Moeller, M.S.; Schellmann, G. Application of remote sensing technologies to map the structural geology of central region of Kenya. IEEE J. Sel. Top. Appl. Earth Obs. Remote Sens. 2015, 8, 1855-1867. [CrossRef] 